\title{
Physiological responses of Elaeocarpus glabripetalus seedlings exposed to simulated acid rain and cadmium
}

\author{
Liu, Meihua
}

2019-07-15

Liu , M , Korpelainen , H , Dong , L \& Yi , L 2019 , ' Physiological responses of Elaeocarpus glabripetalus seedlings exposed to simulated acid rain and cadmium ' , Ecotoxicology and Environmental Safety, vol. 175 , pp. 118-127 . https://doi.org/10.1016/j.ecoenv.2019.03.026

http://hdl.handle.net/10138/328166

https://doi.org/10.1016/j.ecoenv.2019.03.026

cc_by_nc_nd

acceptedVersion

Downloaded from Helda, University of Helsinki institutional repository.

This is an electronic reprint of the original article.

This reprint may differ from the original in pagination and typographic detail.

Please cite the original version. 


\section{Physiological responses of Elaeocarpus glabripetalus}

\section{2 seedlings exposed to simulated acid rain and cadmium}

3 Meihua Liu ${ }^{1}$, Helena Korpelainan ${ }^{2}$, Lianchun Dong ${ }^{1}$, Lita $\mathrm{Yi}^{1,+}$

$4 \quad{ }^{1}$ School of Forestry and Biotechnology, Zhejiang Agriculture and Forestry University,

5 Lin'an, 311300, China

$6 \quad{ }^{2}$ Department of Agricultural Sciences, Viikki Plant Science Centre, P.O. Box 27

7 (Latokartanonkaari 5), FI-00014 University of Helsinki, Finland

$8+$ Corresponding author: Lita Yi, Email: yilita@126.com

9 


\section{Abstract}

Combined effects of cadmium $(\mathrm{Cd})$ and acid rain on physiological and biochemical characteristics in Eleocarpus glabripetalus seedlings were investigated under controlled conditions. The single $\mathrm{Cd}$ treatment and the combined $\mathrm{Cd}$ and acid rain treatment increased growth at low $\mathrm{Cd}$ concentrations, while decreased growth and photosynthesis at high $\mathrm{Cd}$ concentrations. A low $\mathrm{Cd}$ concentration $\left(50 \mathrm{mg} \cdot \mathrm{kg}^{-1}\right)$ combined with different acid rain treatments increased the seedling biomass, while there was no significant difference in chlorophyll fluorescence and antioxidative enzyme activities compared with the control plants. A high Cd concentration (100 $\mathrm{mg} \cdot \mathrm{kg}^{-1}$ ) under different acid rain treatments significantly decreased the biomass, the Fe and Mg content, chlorophyll fluorescence, photosynthetic parameters (the maximum net photosynthetic rate, $A_{\max }$, and the light saturation point, $\left.L_{S P}\right)$. Relative electric conductivity and peroxidase (POD) activity were significantly higher while the reduced glutathione (GSH) content and catalase (CAT) activity were significantly lower at high $\mathrm{Cd}$ concentration under acid rain when compared to the control plants. The results indicated that the combination of a high concentration of $\mathrm{Cd}$ and acid rain aggravated the toxic effect of $\mathrm{Cd}$ or acid rain alone on the growth and physiological parameters of E. glabripetalus due to serious damage to the chloroplast structure. However, E. glabripetalus showed tolerance to a low concentration of $\mathrm{Cd}$ and low $\mathrm{pH}$ induced by acid rain.

Additional Key words: Interactive effects; Cadmium; Acid rain; Physiology; Elaeocarpus glabripetalus. 


\section{Abbreviation}

$A Q Y$ - apparent quantum; $A_{\max }$ - maximum net photosynthetic rate; CAT - catalase;

Chl - chlorophyll; GSH - glutathione; $F_{m}$ - maximal fluorescence in dark-adapted state; $F_{m}{ }^{\prime}$ - maximal fluorescence in the light-adapted state; $F_{S}$ - steady state value of fluorescence; $F_{v}-$ variable fluorescence; $F_{v} / F_{m}-$ maximum quantum yield; $F_{\mathrm{v}} / F_{0}-$ potential activity of PSII; $F_{0}{ }^{\prime}-$ basal fluorescence after farred illumination; $L_{C P}-$ light compensation point; $L_{S P}-$ light saturation point; $N P Q$ - non-photochemical quenching of fluorescence; PAR - photosynthetically active radiation; $P_{n}-$ net photosynthetic rate; POD - peroxidase; PSII - photosystem II; PPFD - photosynthetic photon flux density; $q P$ - photochemical quenching; ROS - reactive oxygen species 


\section{Introduction}

Cadmium (Cd) is one of the most toxic elements that can be found as a contaminant in the soil. According to Zhou et al. (2004) and Jin et al. (2010), the concentration of Cd in some severe polluted soils was higher than $100 \mathrm{mg} \cdot \mathrm{kg}^{-1}$. Cadmium contents in soil have dramatically increased during recent years and its toxicity limits plant growth and development. Cadmium can be easily taken up by roots and it tends to accumulate within plant organs (Gill et al., 2012). Cd inhibits plant growth and biomass production, affects mineral uptake, photosynthesis and the protective system, and negatively interferes with essential physiological processes (Januškaitienė, 2012, Parmar et al., 2013, Li et al., 2015, Liu et al., 2017,).

In the nature, plants are rarely exposed to a single hazardous stress. Different contaminants may show additive, antagonistic or synergistic interactions. Acid rain is one of the well-known environmental problems, which cause negative impacts on plant growth and health. It has been found that acid rain destroys leaves, causes deleterious effects on photosynthesis and inhibits growth (Sun et al., 2016, Debnath et al., 2018). Most agroforestry areas with acid rain pollution have also other contaminants, such as $\mathrm{Cd}$, leading to combined pollutions effects, which are major problems for sustainable forestry and environmental safety.

There are many previous investigations on the effects of acid rain or $\mathrm{Cd}$ alone on plants (Chmielowska-Bąk et al., 2014, Li et al., 2015, Zheng et al., 2017, Ren et al., 2018), while only a few studies have reported results on their combined adverse effects on plant growth ( Liao et al., 2003, Liu et al., 2011, Sun et al., 2012). Such 
combined pollution could have harmful effects on plant growth through the inhibition of photosynthesis, because the photosynthetic apparatus appears especially sensitive to $\mathrm{Cd}$ (Gill et al., 2012). Previous studies have found that $\mathrm{Cd}$ combined with acid rain may damage the chloroplast structure, thus reducing photosynthesis (Sun et al., 2012), and decrease the activities of antioxidative enzymes (Liu et al., 2011). The combined effect of acid rain and heavy metal exposure would inhibit plant growth through reducing biomass and mineral uptake (Zhang et al., 2016). Many of the previous studies on the combined effect of heavy metals and acid rain have focused on crops and only few on woody plants. Compared with herbaceous plants, woody plants usually grow slowly with a deep root system and long generation time, and they are more easily affected adversely by pollution.

Eleocarpus glabripetalus is a heliophilous and dominant species in forest ecosystems of China. It is widely distributed in regions affected by severe acid rain but also by $\mathrm{Cd}$ pollution. Our previous studies showed that E. glabripetalus seedlings have tolerance to acid rain (Liu et al., 2015). However, we don't know how it would grow under the combined pollution of acid rain and Cd. Therefore, the objectives of our present study are: (1) to investigate the responses of chlorophyll fluorescence and photosynthetic parameters to the combined pollution of $\mathrm{Cd}$ and acid rain; (2) to reveal the activities of antioxidative enzymes and the content of reduced glutathione (GSH) under the combined pollution of $\mathrm{Cd}$ and acid rain; (3) to show the combined effect on biomass allocation, and on the content of $\mathrm{Cd}, \mathrm{Mg}$ and $\mathrm{Fe}$ in plants. The results obtained from this study will enhance understanding of the mechanisms of tolerance to the combined 
pollution of $\mathrm{Cd}$ and acid rain in E. glabripetalus.

\section{Materials and methods}

\subsection{Preparation of simulated acid rain and Cd solution}

According to the average $\mathrm{pH}$ value of acid rain in southern China (Hangzhou

Muncipal Environmental Protection, 2013), two pH values (pH 3.0 and 5.6) were selected for the experiment. Correspondingly, according to the average concentration of Cd in polluted soil ( Zhou et al., 2004, Jin et al., 2010), the final concentrations of 50 and $100 \mathrm{mg} \cdot \mathrm{kg}^{-1}$ were selected. Two solutions were prepared: (1) According to the general anion composition of rainfall in southern China, the $\mathrm{SO}_{4}{ }^{-2} / \mathrm{NO}_{3}{ }^{-}$ratio is 2,87 (Xu et al., 2011). Considering that the proportion of $\mathrm{NO}_{3}{ }^{-}$has been rising during recent years, a simulated acid rain solution stock of $\mathrm{pH} 3.0$ was prepared with a $\mathrm{H}_{2} \mathrm{SO}_{4}$ and $\mathrm{HNO}_{3}$ ratio of 1.0:1.0 (v/v), and then used as such or diluted to $\mathrm{pH} 5.6$ to be utilized as the spraying solution to simulate acid rain. (2) The Cd solutions $(0.15$ $\mathrm{mM}$ and $0.30 \mathrm{mM}$, calculated for $10 \mathrm{~kg}$ soil in the pot and 100-day stress according to 50 and $100 \mathrm{mg} \cdot \mathrm{kg}^{-1}$ ) were prepared by dissolving appropriate quantities of $\mathrm{CdCl}_{2} \cdot 5 \mathrm{H}_{2} \mathrm{O}$ (Chemical Co. Ltd., China) in distilled water (pH 7.0).

\subsection{Plant material and stress treatments}

The soil, a mixture of reddish brown forest soil, was sampled from the depth of 0-20 $\mathrm{cm}$. Then, the soil sample was air-dried and ground to pass through a $2 \mathrm{~mm}$ sieve, and $10 \mathrm{~kg}$ was divided into each pot. The initial soil $\mathrm{pH}$ was 6.88 and available $\mathrm{Cd}$ was $0.082 \mathrm{mg} \cdot \mathrm{kg}^{-1}$. Healthy one-year old seedlings of E. glabripetalus with height of 40- 
$60 \mathrm{~cm}$ and a basal diameter of approximately $0.8-1.0 \mathrm{~cm}$ were planted into pots with an inner diameter of $30 \mathrm{~cm}$ and a depth of $40 \mathrm{~cm}$, one seedling per pot. A PVC plate was placed under each pot. The seedlings were kept under a canopy in the Botanical Garden of the Zhejiang Agriculture and Forestry University $\left(119^{\circ} 44^{\prime}\right.$ E, $\left.30^{\circ} 16^{\prime} \mathrm{N}\right)$, East China. After growing for two months, seedlings were subjected to 9 treatments of $\mathrm{Cd}$ and simulated acid rain, (1) The control group (CK): E. glabripetalus seedlings were watered daily by distilled water (pH 7.0) without Cd. (2) Single treatment with Cd: soil was sprayed daily with Cd solutions $(0.15 \mathrm{mM}$ or $0.30 \mathrm{mM})$. (3) Single treatment with simulated acid rain: E. glabripetalus seedlings were sprayed daily with acid rain solutions (pH 3.0 or 5.6) on leaves. (4) Combined treatment with $\mathrm{Cd}$ and simulated acid rain: E. glabripetalus seedlings were sprayed with acid rain solutions (pH 3.0 or 5.6) on leaves and $\mathrm{Cd}$ solutions $(0.15 \mathrm{mM}$ or $0.30 \mathrm{mM})$ into soil every day. For these 9 treatments, the amount of simulated acid rain or distilled water or $\mathrm{Cd}$ solutions was $300 \mathrm{~mL}$ per pot every day, as calculated according to precipitation and evaporation in southeastern China. All treatments were replicated in 12 pots. During the 100-day experiment, the places of pots were often randomly switched to avoid differences in microclimate.

\subsection{Measurements of chlorophyll fluorescence and photosynthetic parameters}

After the 100-day experiment, chlorophyll fluorescence was measured from 09:0011:30 a.m. using a portable chlorophyll fluorometer (PAM-2000 WALZ, Germany). Three seedlings were selected from each treatment, with measurements performed for 
a leaf from the upper, middle and lower parts of the plant. The sampled leaves were dark-adapted for 20 minutes using a dark leaf clip before each chlorophyll fluorescence measurement. The initial fluorescence $\left(F_{0}\right)$, which was measured using an analytical light of $0.05 \mu \mathrm{mol} \mathrm{m} \mathrm{m}^{-2} \mathrm{~s}^{-1}$ PFD, was recorded after dark adaptation and, subsequently, a saturating pulse $\left(6,000 \mu \mathrm{mol} \mathrm{m} \mathrm{m}^{-2} \mathrm{~s}^{-1} \mathrm{PFD}, 2 \mathrm{~s}\right)$ was given to measure the maximal fluorescence $\left(F_{m}\right)$. The steady state value of fluorescence $\left(F_{s}\right)$, the maximal fluorescence in the light-adapted state $\left(F_{m}\right)$ and the basal fluorescence after farred illumination $\left(F_{0}{ }^{\prime}\right)$ were determined by a procedure described by Guo (2005), with six measurements conducted per replication. The maximum quantum yield $\left(F_{v} /\right.$ $\left.F_{m}\right)$ was determined by $F_{\mathrm{v}} / F_{\mathrm{m}}=\left(F_{\mathrm{m}}-F_{\mathrm{o}}\right) / F_{m} . F_{v}$ is variable fluorescence calculated as $F_{v}=F_{m}{ }^{\prime}-F_{0}{ }^{\prime}$. Non-photochemical quenching of fluorescence $(N P Q)$ was calculated as $N P Q=\left(F_{m}-F_{m}{ }^{\prime}\right) / F_{m}{ }^{\prime}$. Potential activity of photosystem II (PSII) $\left(F_{v} / F_{0}\right)$ was calculated by $F_{v} / F_{0}=\left(F_{m}-F_{0}\right) / F_{0}$. Photochemical quenching $(\underline{q P})$ was calculated by $q P=\left(F_{m}^{\prime}-F_{s}\right) /\left(F_{m}{ }^{\prime}-F_{0}{ }^{\prime}\right)$.

Photosynthetic parameters were measured for the same leaves at the same time as for chlorophyll fluorescence, using a portable photosynthesis system, Li-6400 (Li-Cor Inc. Lincoln, Nebraska, USA). Leaf temperature was $25^{\circ} \mathrm{C}$ with a relative humidity of $80 \%$ inside the leaf chamber during measuring. Photosynthetic photon flux density (PPFD) was controlled at $500 \mu \mathrm{mol} \cdot \mathrm{m}^{-2} \cdot \mathrm{s}^{-1}$. Ambient $\mathrm{CO}_{2}$ concentration was $400 \pm 5$ $\mu \mathrm{mol} \cdot \mathrm{mol}^{-1}$. Responses to photosynthetically active radiation (PAR) were measured at $0,10,20,50,80,100,200,300,500$ and $800 \mu \mathrm{mol} \cdot \mathrm{m}^{-2} \cdot \mathrm{s}^{-1}$. Net photosynthetic rate $\left(P_{n}\right)$ - PAR response curves were generated by plotting $P_{n}$ as a function of PAR. These 
152

153

154

155

156

157

158

159

160

161

162

163

164

165

curves were modeled by fitting data to a nonrectangular hyperbola (Lambers et al., 1998) by means of the nonlinear least squares curve-fitting procedure of Photosyn Assistant software (Dundee Scientific, Scotland, UK). This model is expressed as follows:

$P_{n}=\left[A Q Y \times P A R+A_{\max }-\operatorname{sqrt}\left[\left(A Q Y \times P A R+A_{\max }\right)^{2}-4 \times A Q Y \times A_{\max } \times P A R \times K\right] / 2 \times K\right]-R_{d}$ where $A Q Y$ is apparent quantum yield $\left[\mu \mathrm{mol}\left(\mathrm{CO}_{2}\right) \mu \mathrm{mol}^{-1}\right.$ (photon)], PAR is the photosynthetic active radiation, $A_{\max }$ is the maximum net photosynthetic rate, $K$ is the curvature factor, and $R_{d}$ is leaf-level "dark" respiration $\left[\mu \mathrm{mol}\left(\mathrm{CO}_{2}\right) \cdot \mathrm{m}^{-2} \cdot \mathrm{s}^{-1}\right]$. Light saturation point $\left(L_{S P}\right)$ and light compensation point $\left(L_{C P}\right)$ were estimated.

\subsection{Measurements of antioxidant system}

$1 \mathrm{~g}$ leaves from control and treated plants were ground in liquid nitrogen, then extracted with $50 \mathrm{mM}$ potassium phosphate buffer $(\mathrm{pH} 7.8)$ containing $0.1 \mathrm{mM}$ EDTA, 1\% (w/v) PVP, $0.1 \mathrm{mM} \mathrm{PMSF}$, and $0.2 \%(\mathrm{v} / \mathrm{v})$ Triton X100 for the measurements of peroxidase (POD) and catalase (CAT) activities and the content of reduced glutathione (GSH). The homogenate was centrifuged at $14000 \times \mathrm{g}$ at $4^{\circ} \mathrm{C}$ for $15 \mathrm{~min}$. The supernatants were used for the enzyme assays. The means $\pm \mathrm{SE}$ were calculated from the data of at least 3 independent measurements.

POD activity was determined by monitoring the increase in absorbance at $470 \mathrm{~nm}$ during the oxidation of guaiacol (Upadhyaya et al., 1985). The amount of enzyme producing $1 \mu \mathrm{mol} / \mathrm{min}$ of oxidized guaiacol was defined as $1 \mathrm{U}$. CAT activity was determined by UV spectrophotometry by a direct measurement of $\mathrm{H}_{2} \mathrm{O}_{2}$ 
decomposition at $240 \mathrm{~nm}$, following the procedure of Aebi (1984); $1 \mathrm{U}$ equals the amount of $\mathrm{H}_{2} \mathrm{O}_{2}$ (in $\mu$ mol) decomposed in $1 \mathrm{~min}$.

Reduced (GSH) contents were measured according to Griffith (Griffith, 1980). The contents were determined in a reaction mixture containing leaf extract, $100 \mathrm{mM}$ sodium phosphate buffer ( $\mathrm{pH}$ 7.7) and $100 \mathrm{mM}$ sodium phosphate buffer ( $\mathrm{pH} 6.8)$ containing $4 \mathrm{mM}$ 5, 5-dithiobis-(2-nitrobenzoic acid) (DTNB). The reaction mixture was maintained at $25^{\circ} \mathrm{C}$ for 10 min and the absorbance was read at $412 \mathrm{~nm}$. A standard graph was drawn using different concentrations of a GSH solution. With the help of the standard graph, reduced GSH contents in the leaves were calculated.

Relative electric conductivity was determined using the conductivity instrument. First, $1 \mathrm{~g}$ fresh leaves were cut and completely immersed in $20 \mathrm{ml}$ deionized water, and then degassed for $15 \mathrm{~min}$. The initial conductivity $\left(\mathrm{E}_{1}\right)$ was measured with a conductivity instrument (LC116, Mettler Toledo Instruments Co., Ltd, Shanghai, China) after 30 mins. The solution was then incubated at $100^{\circ} \mathrm{C}$ for $15 \mathrm{~min}$ and cooled to room temperature, and the final conductivity $\left(\mathrm{E}_{2}\right)$ was determined. The conductivity of deionized water was also determined as blank conductivity $\left(\mathrm{E}_{0}\right)$. The relative conductivity was calculated according to the following formula: relative electric conductivity $(\%)=\left(E_{1}-E_{0}\right) /\left(E_{2}-E_{0}\right) \times 100 \%$.

\subsection{Measurements of biomass, and element and Cd contents of plants}

Three replicated plants from each treatment were harvested at 100 days. Plant parts, such as stems, leaves and roots (carefully washed and blotted), were separated and dried in an oven at $80^{\circ} \mathrm{C}$ for $48 \mathrm{~h}$ to constant weight and weighed. Dry mass 
accumulation was then calculated. The contents of elements $(\mathrm{Mg}, \mathrm{Fe}$ and $\mathrm{Cd})$ in the leaves, stems and roots of E. glabripetalus were measured by ICP-AES (PerkinElmer Inc., Shelton, CT, USA) with three replicates per treatment.

\subsection{Data analysis}

The significance of differences between the treatments was analyzed by one-way analysis of variance (ANOVA) using SPSS17.0. The interactions between Cd and acid rain were analyzed by the two-way analysis of ANOVA. Prior to analysis, the data were checked for normality and homogeneity of variances. Differences between treatments were detected and mean values were compared by the Tukey's test ( $p=$ 0.05). All data were expressed as means $\pm \operatorname{SE}(n \geq 3)$.

\section{Results}

\subsection{Effects of Cd and acid rain on chlorophyll fluorescence in E. glabripetalus} seedlings

Fig.1 shows the changes in chlorophyll fluorescence parameters when $E$. glabripetalus seedlings were treated with $\mathrm{Cd}$ and acid rain. When treated with acid rain only, the $F_{v} / F_{m}, N P Q, q P$ and $F_{v} / F_{0}$ values of $E$. glabripetalus seedlings increased compared with control plants. $F_{v} / F_{m}$ decreased by $1.20 \%$ at $\mathrm{pH} 5.6$ and increased by $0.41 \%$ at $\mathrm{pH} 3.0 . N P Q, q P$ and $F_{v} / F_{0}$ increased by $8.99 \%, 2.66 \%$ and $0.46 \%$, respectively, at $\mathrm{pH} 5.6$, and increased by $10.99 \%, 1.75 \%$ and $0.37 \%$, respectively at $\mathrm{pH} 3.0$. When E. glabripetalus seedlings were treated with $\mathrm{Cd}$ alone, $F_{v} / F_{m}$ decreased by $1.22 \%$ and $2.98 \%$ at 50 and $100 \mathrm{mg} \cdot \mathrm{kg}^{-1} \mathrm{Cd}$, respectively, in comparison with the control plants. $N P Q, q P$ and $F_{v} / F_{0}$ increased by $16.63 \%, 0.63 \%$ 
and $1.06 \%$, respectively, at $50 \mathrm{mg} \cdot \mathrm{kg}^{-1} \mathrm{Cd}$, while they decreased by $8.36 \%, 2.11 \%$ and $9.88 \%$, respectively, at $100 \mathrm{mg} \cdot \mathrm{kg}^{-1} \mathrm{Cd}$.

When E. glabripetalus seedlings were treated with acid rain and $50 \mathrm{mg} \cdot \mathrm{kg}^{-1} \mathrm{Cd}, F_{v} /$ $F_{m}$ increased by $0.64 \%$ at $\mathrm{pH} 5.6$ and $0.08 \%$ at $\mathrm{pH} 3.0$ compared with the control plants, by $1.86 \%$ and $1.88 \%$ compared with the single treatment with $\mathrm{pH} 5.6$ acid rain and the single treatment of $50 \mathrm{mg} \cdot \mathrm{kg}^{-1} \mathrm{Cd}$, respectively (Fig.1). However, when $E$. glabripetalus seedlings were treated with acid rain and $100 \mathrm{mg} \cdot \mathrm{kg}^{-1} \mathrm{Cd}, F_{v} / F_{m}$ decreased compared with control or acid rain-treated plants. $N P Q, q P$ and $F_{v} / F_{0}$ decreased by $7.05 \%, 2.51 \%$ and $5.80 \%$, compared with control plants. Decreases in $N P Q, q P$ and $F_{v} / F_{0}$ were found in some combined treatments with $\mathrm{Cd}$ and acid rain. For example, when the seedlings were treated with acid rain at $\mathrm{pH} 3.0$ and $100 \mathrm{mg} \cdot \mathrm{kg}^{-}$

${ }^{1} \mathrm{Cd}, N P Q$ decreased by $22.40 \%, 30.08 \%$ and $15.32 \%$, respectively, compared with control plants and those treated with $100 \mathrm{mg} \cdot \mathrm{kg}^{-1} \mathrm{Cd}$ alone and acid rain at $\mathrm{pH} 3.0$ alone, respectively. The two-way ANOVA analysis indicated that there was no interaction between $\mathrm{Cd}$ and acid rain on chlorophyll fluorescence parameters $\left(F_{v} / F_{m}\right.$, $N P Q, q P$ and $\left.F_{v} / F_{0}\right)$. The values of $N P Q, q P$ and $F_{v} / F_{0}$ of $E$. glabripetalus seedlings kept under the combined treatment with a high concentration of $\mathrm{Cd}\left(100 \mathrm{mg} \cdot \mathrm{kg}^{-1}\right)$ and low $\mathrm{pH}$ acid rain $(\mathrm{pH} 3.0)$ were lower than those in seedlings exposed to a single treatment with $\mathrm{Cd}$ or acid rain, indicating that $100 \mathrm{mg} \cdot \mathrm{kg}^{-1} \mathrm{Cd}$ and $\mathrm{pH} 3.0$ acid rain have a synergistic effect on most chlorophyll fluorescence parameters.

\subsection{Effects of $C d$ and acid rain on photosynthetic parameters in E. glabripetalus} seedlings 
When the seedlings were treated with acid rain only, $A_{\max }$ increased at $\mathrm{pH} 3.0$ and $\mathrm{pH}$ 5.6 compared with control seedlings $(p>0.05$ ) (Table 1$) . \quad A_{\max }$ increased by $30.36 \%$ at $\mathrm{pH} 5.6$ and $11.04 \%$ at $\mathrm{pH} 3.0$. When the seedlings were treated with $\mathrm{Cd}$ alone, $A_{\max }$ increased by $52.65 \%$ at $50 \mathrm{mg} \cdot \mathrm{kg}^{-1} \mathrm{Cd}$, while it decreased slightly at $100 \mathrm{mg} \cdot \mathrm{kg}^{-1} \mathrm{Cd}$ compared with control seedlings. However, when E. glabripetalus seedlings were treated with acid rain and $50 \mathrm{mg} \cdot \mathrm{kg}^{-1} \mathrm{Cd}, A_{\max }$ increased by $1.49 \%$ at $\mathrm{pH} 5.6$ and $15.07 \%$ at $\mathrm{pH} 3.0(p>0.05)$, while there was a decrease by $57.96 \%$ at $\mathrm{pH} 5.6$ and $39.07 \%$ at $\mathrm{pH} 3.0$ under $100 \mathrm{mg} \cdot \mathrm{kg}^{-1} \mathrm{Cd}$ treatment $(p>0.05) . A Q Y$ increased when the seedlings were treated with acid rain or Cd treatment only. The combined treatment with pH 3.0 acid rain increased $A Q Y$ by $80 \%$ at $50 \mathrm{mg} \cdot \mathrm{kg}^{-1} \mathrm{Cd}$ and by $56 \%$ at 100 $\mathrm{mg} \cdot \mathrm{kg}^{-1} \mathrm{Cd}(p<0.05)$. Compared with control plants, $L_{C P}$ decreased in seedlings treated with acid rain or Cd only $(p<0.05)$. When E. glabripetalus seedlings were treated with pH 3.0 acid rain and $\mathrm{Cd}, L_{C P}$ decreased by $57.89 \%$ at $50 \mathrm{mg} \cdot \mathrm{kg}^{-1} \mathrm{Cd}$ and by $21.05 \%$ at $100 \mathrm{mg} \cdot \mathrm{kg}^{-1} \mathrm{Cd} . L_{S P}$ increased at $50 \mathrm{mg} \cdot \mathrm{kg}^{-1} \mathrm{Cd}$ and decreased at 100 $\mathrm{mg} \cdot \mathrm{kg}^{-1} \mathrm{Cd}(p<0.05)$, and acid rain treatment alone decreased $L_{S P}(p<0.05)$. Under a combined treatment with acid rain and $100 \mathrm{mg} \cdot \mathrm{kg}^{-1} \mathrm{Cd}, L_{S P}$ decreased by $65.18 \%$ at pH 5.6 and by $54.31 \%$ at $\mathrm{pH} 3.0(p<0.05)$ (Table 1$)$. The two-way ANOVA analysis indicated that there was no interaction effect between $\mathrm{Cd}$ and acid rain on photosynthetic parameters.

\subsection{Effects of $C d$ and acid rain on POD and CAT activities, relative electric} conductivity and GSH content in E. glabripetalus seedlings

When E. glabripetalus seedlings were treated with acid rain alone, POD and CAT 
activities increased along with decreasing $\mathrm{pH}$ values but no significant difference were detected compared with the control plants $(p>0.05)$ (Fig.2). The POD activity increased with an increasing $\mathrm{Cd}$ concentration. At $100 \mathrm{mg} \cdot \mathrm{kg}^{-1} \mathrm{Cd}$, the POD activity was significantly higher than that of the control plants $(p<0.05)$, with an increase of $63.80 \%$. When the seedlings were treated by both acid rain and Cd, the POD activity was significantly higher than that of control plants $(p<0.05)$, increases equaling $176.45 \%$ at $\mathrm{pH} 5.6$ and $226.05 \%$ at $\mathrm{pH} 3.0$ under $100 \mathrm{mg} \cdot \mathrm{kg}^{-1} \mathrm{Cd}$. The CAT activity increased at $50 \mathrm{mg} \cdot \mathrm{kg}^{-1} \mathrm{Cd}(p>0.05)$ while decreased at $100 \mathrm{mg} \cdot \mathrm{kg}^{-1} \mathrm{Cd}(p<0.05)$. The CAT activity was higher than that of control plants under a combination of $\mathrm{pH} 3.0$ acid rain and $50 \mathrm{mg} \cdot \mathrm{kg}^{-1} \mathrm{Cd}$, while the CAT activity was lower under a combination of $100 \mathrm{mg} \cdot \mathrm{kg}^{-1} \mathrm{Cd}$ and $\mathrm{pH} 3.0$ / 5.6 acid rain than that of control plants $(p<0.05)$.

When E. glabripetalus seedlings were treated with single acid rain, relative electric conductivity decreased but showed no significant difference compared with the control plants ( $p>0.05)$, (Fig.2). When treated with Cd alone, relative electric conductivity increased significantly at $100 \mathrm{mg} \cdot \mathrm{kg}^{-1} \mathrm{Cd}(P<0.05)$. Under the combined treatment with acid rain and $100 \mathrm{mg} \cdot \mathrm{kg}^{-1} \mathrm{Cd}$, relative electric conductivity increased by $73.93 \%$ at $\mathrm{pH} 5.6$ and $165.64 \%$ at $\mathrm{pH} 3.0(p<0.05)$.

Compared with the control seedlings, the GSH content decreased under acid rain (Fig.2). At $50 \mathrm{mg} \cdot \mathrm{kg}^{-1} \mathrm{Cd}(p<0.05)$, the GSH content increased but decreased at 100 $\mathrm{mg} \cdot \mathrm{kg}^{-1} \mathrm{Cd}(p<0.05)$. Under the combined treatment with acid rain and $100 \mathrm{mg} \cdot \mathrm{kg}^{-1}$ Cd, the GSH content decreased by $21.30 \%$ at $\mathrm{pH} 5.6$ and $25.16 \%$ at $\mathrm{pH} 3.0(p<0.05)$. The ANOVA analysis showed that there was a significant interaction effect between 
$\mathrm{Cd}$ and acid rain on POD and CAT activities, and on the GSH content. Under the combined treatment with a high concentration of $\mathrm{Cd}$ and low $\mathrm{pH}$ acid rain, the POD and CAT activities of E. glabripetalus seedlings were lower than those under $\mathrm{Cd}$ or acid rain alone, thus indicating that $100 \mathrm{mg} \cdot \mathrm{kg}^{-1} \mathrm{Cd}$ and $\mathrm{pH} 3.0$ acid rain have a synergistic effect on antioxidant enzymes.

\subsection{Effects of $\mathrm{Cd}$ and acid rain on biomass in E. glabripetalus seedlings}

Table 2 shows the biomass accumulation of E. glabripetalus exposed to simulated acid rain and $\mathrm{Cd}$. A acid rain treatment alone increased the total biomass by $15.92 \%$ at pH 5.6 and $20.66 \%$ at $\mathrm{pH} 3.0$ compared with the control plants. The biomass allocation of plants kept in control conditions was $2.99 \%$ in leaves, $46.70 \%$ in stem and $25.31 \%$ in roots. The root biomass increased by $34.98 \%$ at $\mathrm{pH} 5.6$, while there was more biomass in leaves at $\mathrm{pH} 3.0(37.30 \%)$. When the seedlings were treated by $\mathrm{Cd}$ alone, the stem biomass reduced by $38.03 \%$ and $41.47 \%$ at 50 and $100 \mathrm{mg} \cdot \mathrm{kg}^{-1}$ $\mathrm{Cd}$, respectively, in comparison with control plants. Also, $50 \mathrm{mg} \cdot \mathrm{kg}^{-1} \mathrm{Cd}$ increased the total biomass by $20.37 \%$ while $100 \mathrm{mg} \cdot \mathrm{kg}^{-1} \mathrm{Cd}$ decreased the total biomass by $11.00 \%$. The combined acid rain and $\mathrm{Cd}$ stress decreased biomass allocation into the stem. For example, the proportion of biomass in stem was $37.70 \%$ and $37.93 \%$ at $\mathrm{pH}$ 3.0 and 5.6 under $100 \mathrm{mg} \cdot \mathrm{kg}^{-1} \mathrm{Cd}$ treatment, respectively. The total biomass increased under the combined $50 \mathrm{mg} \cdot \mathrm{kg}^{-1} \mathrm{Cd}$ and acid rain treatment $(p>0.05)$, while it decreased under $100 \mathrm{mg} \cdot \mathrm{kg}^{-1} \mathrm{Cd}$ and acid rain $(p<0.05)$. seedlings 
Acid rain treatment alone decreased significantly the $\mathrm{Mg}$ content of stems and leaves compared with the control plants, while the slight decrease in roots was not significant (Table 3). When seedlings were treated by $\mathrm{Cd}$ alone, the $\mathrm{Mg}$ content of roots and stems decreased but not significantly $(p>0.05)$. However, $50 \mathrm{mg} \cdot \mathrm{kg}^{-1} \mathrm{Cd}$ increased the $\mathrm{Mg}$ content of leaves by $6.82 \%$, while $100 \mathrm{mg} \cdot \mathrm{kg}^{-1} \mathrm{Cd}$ decreased it by $30.68 \%(p<$ 0.05) in comparison with the control plants. When the seedlings were treated with the combined stress of $\mathrm{pH} 5.6$ acid rain and $\mathrm{Cd}$, the $\mathrm{Mg}$ content of roots decreased significantly $\left(p<0.05\right.$ ), by $16.20 \%$ and $12.55 \%$ at 50 and $100 \mathrm{mg} \cdot \mathrm{kg}^{-1} \mathrm{Cd}$, respectively. Similarly, the Mg content of leaves decreased significantly compared with control plants $(p<0.05)$ under the combined stress of acid rain and $\mathrm{Cd}$. The total $\mathrm{Mg}$ content of plants decreased under acid rain or $\mathrm{Cd}$ stress alone and under the combined stress.

The acid rain treatment increased the Fe content in roots compared with the control plants $(p<0.05)$ (Table 4). When the seedlings were treated by Cd alone, the Fe content of roots decreased significantly at $100 \mathrm{mg} \cdot \mathrm{kg}^{-1} \mathrm{Cd}(p<0.05)$. However, 50 $\mathrm{mg} \cdot \mathrm{kg}^{-1} \mathrm{Cd}$ increased the Fe content of stems $(p<0.05)$. When the seedlings were exposed to $\mathrm{pH} 5.6$ acid rain and $100 \mathrm{mg} \cdot \mathrm{kg}^{-1} \mathrm{Cd}$, the Fe content of roots decreased significantly compared with control plants $(p<0.05)$. Mostly, there were no significant differences in the Fe contents of stems and leaves between the treatments and controls. The total Fe content of plants increased under acid rain stress alone (pH3.0, $p<0.05$ ) and under the combination of $50 \mathrm{mg} \cdot \mathrm{kg}^{-1} \mathrm{Cd}$ and acid rain, while it decreased under the combined stress of $100 \mathrm{mg} \cdot \mathrm{kg}^{-1} \mathrm{Cd}$ and acid rain $(p<0.05)$. 
The Cd content of plants was higher at $100 \mathrm{mg} \cdot \mathrm{kg}^{-1} \mathrm{Cd}$ compared with $50 \mathrm{mg} \cdot \mathrm{kg}^{-1} \mathrm{Cd}$ (Table 5). Most Cd distributed into roots under exposure to $\mathrm{Cd}$ alone, with the proportions equaling $91.27 \%$ and $91.45 \%$ at 50 and $100 \mathrm{mg} \cdot \mathrm{kg}^{-1} \mathrm{Cd}$, respectively. Acid rain was found to decrease the total Cd content of plants compared with the single Cd treatment. The total Cd content of plants decreased by $24.82 \%$ under the combined treatment with $50 \mathrm{mg} \cdot \mathrm{kg}^{-1} \mathrm{Cd}$ and $\mathrm{pH} 3.0$. However, in most cases, there were no significant differences between the effects of the single Cd treatment and the combined treatment on roots, stems or leaves.

\section{Discussion}

It has been reported that single treatments with $\mathrm{Cd}$ or acid rain decrease photosynthesis (Parmar et al., 2013, Li et al., 2015, Sun et al., 2016). Chlorophyll fluorescence and photosynthetic parameters are easily affected by environmental stress and they are commonly used as sensitive indicators of a plant's photosynthetic performance. In our study on E. glabripetalus seedlings, the treatment by acid rain only increased $F_{v} / F_{m}, N P Q, q P, F_{v} / F_{0}, A_{\max }$ and $A Q Y$, which showed that the absorption of light energy, electron transport, conversion of light energy and net photosynthesis rate increased (Fig. 1 and Table 1). The results were in agreement with previous reports on the effects of acid rain on the photosynthesis in E. glabripetalus (Liu et al., 2015). Both Cd treatments decreased $F_{v} / F_{m}$ and the $100 \mathrm{mg} \cdot \mathrm{kg}^{-1} \mathrm{Cd}$ treatment decreased $N P Q, q P, F_{v} / F_{0}, A_{\max }$ and $A Q Y$. These results showed that high Cd concentrations decrease the light reaction of photosynthesis, conversion of light energy and net photosynthesis rate, resulting in the inhibition of photosynthesis in $E$. 
351

352

glabripetalus seedlings. The effects of $\mathrm{Cd}$ on E. glabripetalus seedling are similar to most reports on other plant species (Santos et al., 2012, Xue et al., 2013). An acid rain treatment alone or a high $\mathrm{Cd}$ concentration decreased $L_{C P}$ and $L_{S P}$ of $E$. glabripetalus seedlings, which indicated enhanced and reduced light use efficacy at low and high light levels, respectively. Interestingly, the combined treatment of $\mathrm{Cd}$ and acid rain did not alleviate the effect induced by the $\mathrm{Cd}$ treatment alone; instead, the combination decreased the chlorophyll fluorescence parameters induced by the $\mathrm{Cd}$ treatment. Thus, the combined stress led to a more serious decrease in the photosynthesis of $E$. glabripetalus seedlings. In addition, the degree of change in chlorophyll fluorescence and photosynthetic parameters in seedlings treated with $\mathrm{Cd}$ and acid rain depended on the concentration of $\mathrm{Cd}$ and the $\mathrm{pH}$ value used to simulate acid rain. In most cases, the combined treatment with $\mathrm{Cd}$ and acid rain decreased $N P Q, q P$ and $F_{v} / F_{0}$, and there was a greater inhibition in the absorption of light energy, electron transport and light reaction than under the $\mathrm{Cd}$ treatment alone (Fig.1).

Using two-way ANOVA analyses, we found that there are no significant interactive effects between $\mathrm{Cd}$ and acid rain on chlorophyll fluorescence and photosynthetic parameters mentioned above. However, the values of $N P Q, q P, F_{v} / F_{0}, A_{\max }$ and $L_{S P}$ in E. glabripetalus seedlings exposed to the combined treatment with a high concentration of $\mathrm{Cd}\left(100 \mathrm{mg} \cdot \mathrm{kg}^{-1}\right)$ and low $\mathrm{pH}$ acid rain $(\mathrm{pH}$ 3.0) decreased more than hose in seedlings exposed to other treatments, indicating that a high concentration $\mathrm{Cd}$ and low $\mathrm{pH}$ acid rain show a synergistic effect on most chlorophyll fluorescence parameters of E. glabripetalus. Our result is different from a previous report that 
showed that there is an interactive effect of $\mathrm{Cd}$ and acid rain on chlorophyll fluorescence parameters in soybean seedlings (Sun et al., 2012). It has been previously shown that a high amount of $\mathrm{Cd}$ in soil can inhibit the chlorophyll biosynthesis, lead to the reduction in chlorophyll contents and photoactivation of PSII (Sun et al., 2012, Dias et al., 2013, Li et al., 2015). We conclude that in $E$. glabripetalus seedlings, the combination of low $\mathrm{pH}$ acid rain and a high $\mathrm{Cd}$ concentration would damage the chloroplast structure and lead to a greater decrease in the chlorophyll fluorescence parameters, net photosynthesis rate and light use efficacy. In general, antioxidant metabolism is regarded as an important mechanism that helps to reduce the excessive accumulation of reactive oxygen species (ROS) induced by environment stress (Chaoui et al., 1997, Zhang et al., 2015). Acid rain or Cd stress can induce membrane damage, increase membrane permeability and the accumulation of free radicals in plants (Chaoui et al., 1997, Mobin and Khan, 2007, Debnath et al., 2018). However, active oxygen-scavenging systems can protect membranes from the deleterious effects (Jaleel et al., 2009). Previous studies have indicated that activities of antioxidant enzymes and relative electric conductivity are correlated with plant tolerance to abiotic stresses. Cd-induced damage has been shown to be negatively correlated with the capacity to increase POD and CAT activities and relative electric conductivity in many plants (Liu et al., 2017). According to our research, single acid rain increased the POD and CAT activities in leaves. Generally, $\mathrm{Cd}$ toxicity can increase (Srivastava et al., 2014) or decrease (Hassan et al., 2005) POD or CAT 
395

activities depending on the stress intensity and duration or on the plant's developmental stage (Liu et al., 2017). However, a low Cd concentration (50 $\mathrm{mg} \cdot \mathrm{kg}^{-1}$ ) increased CAT activity, while a high Cd concentration $\left(100 \mathrm{mg} \cdot \mathrm{kg}^{-1}\right)$ decreased the CAT activity and relative electrolyte leakage in leaves. This is in agreement with a report on soybean published by Liu (2011). Similarly to single Cd or acid rain treatments, the combined treatment with acid rain and Cd increased the POD activity significantly $(p<0.05)$. The combination of a high Cd concentration $\left(100 \mathrm{mg} \cdot \mathrm{kg}^{-1}\right)$ and acid rain ( $\mathrm{pH} 3.0$ and 5.6) inhibited the CAT activity $(p<0.05)$, while the POD activity and relative electrolyte leakage increased (Fig.2). Thus, a moderate $\mathrm{Cd}$ concentration and acid rain induced lipid peroxidation and increased POD and CAT activities, while a high $\mathrm{Cd}$ concentration $\left(100 \mathrm{mg} \cdot \mathrm{kg}^{-1}\right)$ inhibited the CAT activity and increased relative electrolyte leakage. The same effects have been observed in wheat treated with $\mathrm{La}^{3+}$ (d'Aquino et al., 2009) and soybean treated with $\mathrm{La}^{3+}$ and acid rain (Zhang et al., 2015). The increased POD and the decreased CAT could not alleviate the peroxidation damage to the cell membrane. The deleterious effects on the cell membrane aggravated the electrolyte leakage from the cytoplasm (the membrane permeability), as indicated by the increased relative electrolyte leakage. In addition, we analyzed the interaction between $\mathrm{Cd}$ and acid rain on the antioxidant enzyme system of E. glabripetalus seedlings and found that there was a synergistic effect of $\mathrm{Cd}$ and acid rain on the antioxidant enzyme system of E. glabripetalus seedlings.

GSH is a major low molecular-weight free thiol tripeptide in plant and animal cells. It 
417 is involved in the cellular defense against the toxic action of oxyradicals, salinity, 418 acidity and heavy metal (David et al., 2005). GSH serves as an important defense line against ROS to protect cells from oxidative stress damage and to modify metal

420 toxicity . It has been reported that the GSH content of a cell could either decrease or

421 increase under metal exposure (Maity et al., 2018, Kim et al., 2018). When E.

422 glabripetalus seedlings were treated with either acid rain or a high concentration of

$423 \mathrm{Cd}\left(100 \mathrm{mg} \cdot \mathrm{kg}^{-1}\right)$, the GSH content decreased. Also the combination of acid rain and

$424100 \mathrm{mg} \cdot \mathrm{kg}^{-1} \mathrm{Cd}$ decreased the GSH content $(p<0.05)$. This result indicated that GSH

425 is involved in the cellular defense against acid rain and Cd stress and alleviates

426 oxidative stress. It may be an antioxidant intervention strategy to prevent oxidative

427 stress under $\mathrm{Cd}$ and acid rain stress.

428 The total biomass increased when E. glabripetalus seedlings were treated by acid rain, 429 as also reported in our previous study (Liu et al., 2015). The reason may be that 430 nitrogen $(\mathrm{N})$ is added into the soil in the acid rain, which then accelerates the biomass 431 accumulation. We found that a high $\mathrm{pH}$ value enhances biomass accumulation in 432 leaves, while a low $\mathrm{pH}$ value facilitates root growth. However, a low $\mathrm{Cd}$ concentration $433\left(50 \mathrm{mg} \cdot \mathrm{kg}^{-1} \mathrm{Cd}\right)$ (with or without acid rain) increases the total biomass, while a high 434 Cd concentration (100 $\mathrm{mg} \cdot \mathrm{kg}^{-1}$ ) (with or without acid rain) decreases the total 435 biomass. It has been found also in soybean that a low $\mathrm{Cd}$ concentration shows a positive effect on biomass accumulation (Liu et al., 2011). Yet, despite the different

437 effects of $\mathrm{Cd}$ and acid rain the, two-way ANOVA analysis indicated that there was no 438 significant interaction between $\mathrm{Cd}$ and acid rain on the total biomass of $E$. 
glabripetalus seedlings.

$\mathrm{Cd}$, which is a common heavy metal pollutant in soil, could accumulate within plant organs and negatively affect essential physiological processes, thus limiting plants' productivity (Gill et al., 2012). The exposure of E. glabripetalus to Cd stress leads to an accumulation of Cd mainly in roots ( $>90 \%)$. These results are consistent with other reports showing that $\mathrm{Cd}$ is mainly retained in roots (Gill et al., 2012, Dias et al., 2013). Partitioning of heavy metals in different plant organs is a strategy to avoid toxicity for a plant (López-Climent et al., 2011, Dias et al., 2013).

Acid rain was found to decrease the total $\mathrm{Cd}$ content of plants compared with the single treatment of $\mathrm{Cd}$. The total $\mathrm{Cd}$ content in plants decreased evenly by $24.8 \%$ at $50 \mathrm{mg} \cdot \mathrm{kg}^{-1} \mathrm{Cd}$ and $\mathrm{pH} 3.0$ acid rain. There is a competition between $\mathrm{H}^{+}$and $\mathrm{Cd}^{2+}$ uptake (Li et al., 2009). At low pH, Cd is likely to form insoluble recipitates with thiol base synthesized by sulphur ions under acid rain, which may inhibit the absorption of $\mathrm{Cd}$ and affect the $\mathrm{Cd}$ transportation in plants. However, in most cases, there were no significant differences between the effects of single Cd treatments and combined treatments on roots, stems or leaves. We suggest that an acid rain treatment inhibits $E$. glabripetalus seedlings from absorbing more $\mathrm{Cd}$, leading to a higher accumulation of $\mathrm{Cd}$ in roots when compared to a single $\mathrm{Cd}$ treatment.

Ii is important to notice that $\mathrm{Cd}$ influences the uptake of other mineral nutrients in plant (Dias et al., 2013). In this study, we detected a significant reduction of Fe and $\mathrm{Mg}$ only at a high $\mathrm{Cd}$ concentration, which suggests that $\mathrm{Cd}$ interferes with the translocation of micronutrients to leaves and roots. Fe plays an important role in 
461 electron transfer, because it is a cofactor in the photosynthetic processes, such as PSII

462 and PSI. Although acid rain increases the total amount of $\mathrm{Fe}$ in plants, $\mathrm{Cd}$-induced $\mathrm{Fe}$

463 deficiency affects the photosynthetic electron transport. In agreement with this, the

464 reduction in $F_{v} / F_{m}$ may be associated to the decreased amount of Fe. These results

465 are similar to those reported in other plant species (López-Millán et al., 2009, Dias et

466 al., 2013). Fe and Cd have similar binding sites at the cell; therefore, a high

467 concentration of $\mathrm{Cd}$ leads to a decrease in $\mathrm{Fe}$ absorption by the cell. $\mathrm{Mg}$ is an essential

468 component of the chlorophyll (Chl) molecule with a very important role in

469 photosynthesis, such as Chl biosynthesis and photochemical reactions (Peng et al.,

470 2015). In addition, $\mathrm{Mg}$ acts as a cofactor for many enzymes and functions in many

471 other physiological processes, such as the formation of reactive oxygen species (ROS)

472 and related photooxidative damage (Verbruggen and Hermans, 2013, Peng et al.,

473 2015). The total Mg content in plants decreased under acid rain, Cd stress and the

474 combined acid rain and Cd stress. The decrease in $\mathrm{Mg}$ might cause an increase in the

475 production of ROS and antioxidant enzymes and, furthermore, impaired

476 photosynthesis (Peng et al., 2015). Our results clearly showed that under a low Cd

477 concentration and acid rain, decreases in $\mathrm{Mg}$ in the roots and leaves of $E$.

478 glabripetalus caused decreases in $A_{\max }$ and $L_{C P}$, and increases in the POD and CAT

479 activities, GSH content and relative electric conductivity.

\section{Conclusion}


482 (1) Combined treatment of a high concentration of $\mathrm{Cd}\left(100 \mathrm{mg} \cdot \mathrm{kg}^{-1}\right)$ and low $\mathrm{pH}$ acid 483 rain $(\mathrm{pH} 3.0)$ decreased $N P Q, q P, F_{v} / F_{0}, A_{\max }$ and $L_{S P}$ in E. glabripetalus seedlings, 484 indicating that $\mathrm{Cd}$ and acid rain have a synergistic effect on most chlorophyll 485 fluorescence and photosynthesis parameters. (2) Combined treatment of a moderate concentration of $\mathrm{Cd}\left(50 \mathrm{mg} \cdot \mathrm{kg}^{-1}\right)$ and acid rain increased POD and CAT activities, GSH content and relative electric conductivity, while the combined stress with a high concentration of $\mathrm{Cd}$ and low $\mathrm{pH}$ acid rain decreased the GSH content and CAT activity. (3) Combined treatment of high concentration of Cd (100 $\left.\mathrm{mg} \cdot \mathrm{kg}^{-1}\right)$ and acid rain decreased the total biomass and changed biomass allocation into different plant organs. (4) Cd mainly accumulated in roots, and acid rain decreased the total $\mathrm{Cd}$ content. (5) Combined treatment of a high concentration of $\mathrm{Cd}\left(100 \mathrm{mg} \cdot \mathrm{kg}^{-1}\right)$ and acid rain decreased $\mathrm{Fe}$ and $\mathrm{Mg}$ contents, further resulting in the inhibition of photosynthesis, increases or decreases in the antioxidant enzyme activities, and reduction in biomass.

According to our results, a high concentration of $\mathrm{Cd}\left(100 \mathrm{mg} \cdot \mathrm{kg}^{-1}\right)$ and low $\mathrm{pH}$ acid rain $(\mathrm{pH} 3.0)$ have toxic effects on the physiological processes of plants. Our study provides novel insights into the combined effects of $\mathrm{Cd}$ and acid rain on woody plants and might also serve as a guide to evaluate forest restoration and biological safety in areas with Cd pollution in acid rain.

\section{Acknowledgements}

502 The study was supported by the Natural Science Foundation of Zhejiang Province (2015C33020), the National Key Research and Development Program of China 


\section{References}

Aebi H. 1984. Catalase in vitro. Methods in Enzymology: Academic Press, New York.

Chaoui A, Mazhoudi S, Ghorbal MH, Ferjani EE. 1997. Cadmium and zinc induction of lipid peroxidation and effects on antioxidant enzyme activities in bean (Phaseolus vulgaris L.). Plant Science, 127: 139e147.

Chmielowska-Bąk J, Lefèvre I, Lutts S, Kulik A, Deckert J. 2014. Effect of cobalt chloride on soybean seedlings subjected to cadmium stress. Acta Societatis Botanicorum Poloniae, 83: 201-207.

d'Aquino L, de Pinto MC, Nardi L, Morgana M, Tommasi F. 2009. Effect of some light rare earth elements on seed germination, seedling growth and antioxidant metabolism in Triticum durum. Chemosphere, 75: 900-905.

David MC, Herminia LT, Andrea HN, Rafael MS. 2005. Sulfur assimilation and glutathione metabolism under cadmium stress in yeast, protists and plants. FEMS Microbiology Reviews, 29: 653-671.

Debnath B, Irshad M, Mitra S, Li M, Rizwan HM, Liu S, Pan T, Qiu D. 2018. Acid rain deposition modulates photosynthesis, enzymatic and non-enzymatic antioxidant activities in tomato. International Journal of Environmental Research, 12: 203-214.

Dias M, Monteiro C, Moutinho Pereira J, Correia C, Gonçalves B, Santos C. 2013. Cadmium toxicity affects photosynthesis and plant growth at different levels. Acta Physiologiae Plantarum, 35: 1281-1289.

Gill SS, Khan N, Tuteja N. 2012. Cadmium at high dose perturbs growth, photosynthesis and nitrogen metabolism while at low dose it up regulates sulfur assimilation and antioxidant machinery in garden cress (Lepidium sativum L.). Plant Science, 182: 112-120.

Griffith OW. 1980. Determination of glutathione and glutathione disulfide using glutathione reductase and 2-vinylpyridine. Analytical Biochemistry, 106: 207-212.

Guo DP, Guo YP, Zhao JP, Liu H, Peng Y, Wang QM, Chen JS, Rao GZ. 2005. Photosynthetic rate and chlorophyll fluorescence in leaves of stem mustard (Brassica juncea var. tsatsai) after turnip mosaic virus infection. Plant Science, 168: 57-63.

Hangzhou Muncipal Environmental Protection B. 2013. Report on the State of the Environment in China. Hangzhou, China (In Chinese). 2012.

Hassan MJ, Shao G, Zhang G. 2005. Influence of cadmium toxicity on growth and antioxidant enzyme activity in rice cultivars with different grain cadmium accumulation. Journal of Plant Nutrition, 28: $1259-1270$.

Jaleel CA, Manivannan P, Wahid A, Farooq M, Somasundaram R, Panneerselvam R. 2009. Drought stress in plants: a review on morphological characteristics and pigments composition. International Journal of Agriculture \& Biology, 11: 100-105.

Januškaitienè I. 2012. The effect of cadmium on several photosynthetic parameters of pea (Pisum sativum L.) at two growth stages. Žemdirbyste-Agriculture, 99: 71-76.

Jin CX, Zhou QX, Zhou QX, Fan J. 2010. Effects of chlorimuron-ethyl and cadimum on biomass growth and cadimum accumulation of wheat in the Phaiozem area, Northeast China. Bulletin of Environmental Contamination and Toxicology, 84: 395-400.

Kim H, Kim JS, Kim PJ, Won EJ, Lee YM. 2018. Response of antioxidant enzymes to Cd and Pb exposure in water flea Daphnia magna: differential metal and age - specific patterns. 
Lambers H, Chapin FS, Pons TL. 1998. Plant physiological ecology.: Springer, New York.

Li LZ, Zhou DM, Wang P, Jin SY, Peijnenburg WJ, Reinecke AJ, van Gestel CA. 2009. Effect of cation competition on cadmium uptake from solution by the earthworm Eisenia fetida. Environmental toxicology and chemistry, 28: 1732-8.

Li SL, Yang WB, Yang TT, Chen Y, Ni WZ. 2015. Effects of cadmium stress on leaf chlorophyll fluorescence and photosynthesis of elsholtzia argyi-a cadmium accumulating plant. International Journal of Phytoremediation, 17: 85-92.

Liao BH, Liu HY, Lu SQ, Wang KF, Probst A, Probst JL. 2003. Combined toxic effects of cadmium and acid rain on Vicia faba L. Bulletin of Environmental Contamination and Toxicology, 71: 9981004.

Liu HJ, Zhang CX, Wang JM, Zhou CJ, Feng H, Mahajan MD, Han XR. 2017. Influence and interaction of iron and cadmium on photosynthesis and antioxidative enzymes in two rice cultivars. Chemosphere, 171: 240-247.

Liu MH, Yi LT, Yu SQ, Yu F, Yin XM. 2015. Chlorophyll fluorescence characteristics and the growth response of Elaeocarpus glabripetalus to simulated acid rain. Photosynthetica, 53: 23-28.

Liu TT, Wu P, Wang LH, Zhou Q. 2011. Response of soybean seed germination to cadmium and acid rain. Biological Trace Element Research, 144: 1186-96.

López-Climent MF, Arbona V, Pérez-Clemente RM, Gómez-Cadenas A. 2011. Effects of cadmium on gas exchange and phytohormone contents in citrus. Biologia Plantarum, 55: 187-190.

López-Millán AF, Sagardoy R, Solanas M, Abadía A, Abadía J. 2009. Cadmium toxicity in tomato (Lycopersicon esculentum) plants grown in hydroponics. Environmental and Experimental Botany, 65.

Maity S, Banerjee R, Goswami P, Chakrabarti M, Mukherjee A. 2018. Oxidative stress responses of two different ecophysiological species of earthworms (Eutyphoeus waltoni and Eisenia fetida) exposed to Cd-contaminated soil. Chemosphere, 203: 307-317.

Mobin M, Khan NA. 2007. Photosynthetic activity, pigment composition and antioxidative response of two mustard (Brassica juncea) cultivars differing in photosynthetic capacity subjected to cadmium stress. Journal of Plant Physiology, 164.

Parmar P, Kumari N, Sharma V. 2013. Structural and functional alterations in photosynthetic apparatus of plants under cadmium stress. Botanical Studies, 54: 45.

Peng HY, Qi YP, Lee J, Yang LT, Guo P, Jiang HX, Chen LS. 2015. Proteomic analysis of Citrus sinensis roots and leaves in response to long-term magnesium-deficiency. BMC Genomics, 16: 253.

Ren X, Zhu J, Liu H, Xu X, Liang C. 2018. Response of antioxidative system in rice (Oryza sativa) leaves to simulated acid rain stress. Ecotoxicology and Environmental Safety, 148: 851-856.

Santos RW, Schmidt ÉC, Martins RDP, Latini A, Maraschin M, Horta PA, Bouzon ZL. 2012. Effects of cadmium on growth, photosynthetic pigments, photosynthetic performance, biochemical parameters and structure of chloroplasts in the agarophyte Gracilaria domingensis (Rhodophyta, Gracilariales). American Journal of Plant Sciences, 3: 1077-1084

Srivastava RK, Pandey P, Rajpoot R, Rani A, Dubey RS. 2014. Cadmium and lead interactive effects on oxidative stress and antioxidative responses in rice seedlings. Protoplasma, 251: 1047-1065.

Sun JW, Hu HQ, Li YL, Wang LH, Zhou Q, Huang XH. 2016. Effects and mechanism of acid rain on plant chloroplast ATP synthase. Environmental Science \& Pollution Research, 23: 1-11.

Sun ZG, Wang LH, Chen MM, Wang L, Liang CJ, Zhou Q, Huang XH. 2012. Interactive effects of 

and Environmental Safety, 79: 62-68.

Upadhyaya A, Sankhla D, Davis TD, Sankhla N, Smith BN. 1985. Effect of paclobutrazol on the activities of some enzymes of activated oxygen metabolism and lipid peroxidation in senescing soybean leaves. Journal of Plant Physiology, 121: 453-461.

Verbruggen N, Hermans C. 2013. Physiological and molecular responses to magnesium nutritional imbalance in plants. Plant and Soil, 368: 87-99.

Xu H, Bi XH, Feng YC, Lin FM, Jiao L, Hong SM, Liu WG, Zhang XY. 2011. Chemical composition of precipitation and its sources in Hangzhou, China. Environmental Monitoring and Assessment, 183: 581-592.

Xue XC, Gao HY, Zhang LT. 2013. Effects of cadmium on growth, photosynthetic rate and chlorophyll content in leaves of soybean seedlings. Biologia Plantarum, 57: 587-590

602

603

604

605

606

607

608

609

610
Zhang X, Wang L, Zhou A, Zhou Q, Huang X. 2016. Alterations in cytosol free calcium in horseradish roots simultaneously exposed to lanthanum(III) and acid rain. Ecotoxicology and Environmental Safety, 126: 62-70.

Zhang XB, Du YP, Wang LH, Zhou Q, Huang XH, Sun ZG. 2015. Combined effects of lanthanum (iii) and acid rain on antioxidant enzyme system in soybean roots. PLOS ONE, 10: e0134546.

Zheng S, Pan T, Ma C, Qiu D. 2017. Differential gene expression of longan under simulated acid rain stress. Bulletin of Environmental Contamination and Toxicology, 98: 726-731.

Zhou QX, Kong FX, Zhu L. 2004. Ecotoxicology (in Chinese). Science Press, Beijing. 
611 Table 1 Effects of $\mathrm{Cd}$ and simulated acid rain on photosynthetic parameters, including

612 the maximum net photosynthetic rate $\left(A_{\max }\right)$, apparent quantum yield $(A Q Y)$, light

613 saturation point $\left(L_{S P}\right)$ and light compensation point $\left(L_{C P}\right)$, in Elaeocarpus

614 glabripetalus seedlings.

615

\begin{tabular}{llllll}
\hline $\begin{array}{l}\mathrm{Cd} \\
\left(\mathrm{mg} \cdot \mathrm{kg}^{-1}\right)\end{array}$ & $\begin{array}{l}\text { Acid rain } \\
\mathrm{pH}\end{array}$ & $\begin{array}{l}A_{\max } \\
\left(\mu \mathrm{mol} \mathrm{CO} \cdot \mathrm{m}^{-2} \cdot \mathrm{s}^{-1}\right)\end{array}$ & $\begin{array}{l}A Q Y \\
\left(\mu \mathrm{mol} \mathrm{CO} \cdot \mathrm{m}^{-2} \cdot \mathrm{s}^{-1}\right)\end{array}$ & $\begin{array}{l}L_{C P} \\
\left(\mu \mathrm{mol} \cdot \mathrm{m}^{-2} \cdot \mathrm{s}^{-1}\right)\end{array}$ & $\begin{array}{l}L_{S P} \\
\left(\mu \mathrm{mol} \cdot \mathrm{m}^{-2} \cdot \mathrm{s}^{-1}\right)\end{array}$ \\
\hline 0 & 7.0 & $4.71 \pm 0.02 \mathrm{ab}$ & $0.025 \pm 0.001 \mathrm{c}$ & $30.4 \pm 0.2 \mathrm{ab}$ & $500.8 \pm 34.3 \mathrm{a}$ \\
& 5.6 & $6.14 \pm 0.04 \mathrm{a}$ & $0.053 \pm 0.001 \mathrm{ab}$ & $24.0 \pm 0.3 \mathrm{~b}$ & $260.8 \pm 20.6 \mathrm{bc}$ \\
& 3.0 & $5.23 \pm 0.18 \mathrm{ab}$ & $0.025 \pm 0.001 \mathrm{c}$ & $25.6 \pm 0.2 \mathrm{ab}$ & $364.8 \pm 29.7 \mathrm{~b}$ \\
\hline 50 & 7.0 & $7.19 \pm 0.04 \mathrm{a}$ & $0.281 \pm 0.001 \mathrm{a}$ & $14.4 \pm 0.9 \mathrm{c}$ & $526.4 \pm 32.9 \mathrm{a}$ \\
& 5.6 & $4.78 \pm 0.03 \mathrm{ab}$ & $0.063 \pm 0.001 \mathrm{ab}$ & $17.6 \pm 1.0 \mathrm{bc}$ & $468.8 \pm 27.3 \mathrm{ab}$ \\
& 3.0 & $5.42 \pm 0.19 \mathrm{ab}$ & $0.045 \pm 0.001 \mathrm{~b}$ & $12.8 \pm 1.0 \mathrm{c}$ & $569.6 \pm 47.3 \mathrm{a}$ \\
\hline 100 & 7.0 & $4.69 \pm 0.03 \mathrm{~b}$ & $0.149 \pm 0.001 \mathrm{a}$ & $16.0 \pm 0.6 \mathrm{bc}$ & $96.0 \pm 14.5 \mathrm{c}$ \\
& 5.6 & $1.98 \pm 0.01 \mathrm{c}$ & $0.019 \pm 0.002 \mathrm{c}$ & $38.4 \pm 0.9 \mathrm{a}$ & $174.4 \pm 13.3 \mathrm{c}$ \\
& 3.0 & $2.87 \pm 0.01 \mathrm{c}$ & $0.039 \pm 0.001 \mathrm{bc}$ & $24.0 \pm 0.5 \mathrm{~b}$ & $228.8 \pm 28.6 \mathrm{bc}$ \\
\hline
\end{tabular}

Data are expressed as mean values $\pm \mathrm{SE}$ of three replicates. Significant differences at $p<0.05$ are showed with different letters in each column. 
618 Table 2 Effects of $\mathrm{Cd}$ and simulated acid rain on the biomass in Elaeocarpus

619 glabripetalus seedlings

620

\begin{tabular}{llllll}
\hline $\begin{array}{l}\mathrm{Cd} \\
\left(\mathrm{mg} \cdot \mathrm{kg}^{-1}\right)\end{array}$ & $\begin{array}{l}\text { Acid rain } \\
\mathrm{pH}\end{array}$ & $\begin{array}{l}\text { Leaf biomass } \\
(\mathrm{g})\end{array}$ & $\begin{array}{l}\text { Stem biomass } \\
(\mathrm{g})\end{array}$ & $\begin{array}{l}\text { Root biomass } \\
(\mathrm{g})\end{array}$ & $\begin{array}{l}\text { Total biomass } \\
(\mathrm{g})\end{array}$ \\
\hline 0 & 7.0 & $6.66 \pm 0.42 \mathrm{~b}$ & $11.12 \pm 0.99 \mathrm{a}$ & $6.02 \pm 0.52 \mathrm{~b}$ & $23.80 \pm 1.76 \mathrm{~b}$ \\
& 5.6 & $7.64 \pm 0.84 \mathrm{ab}$ & $10.33 \pm 0.87 \mathrm{ab}$ & $9.65 \pm 0.82 \mathrm{a}$ & $27.62 \pm 2.39 \mathrm{a}$ \\
& 3.0 & $10.71 \pm 0.98 \mathrm{a}$ & $10.25 \pm 0.97 \mathrm{ab}$ & $7.75 \pm 0.85 \mathrm{ab}$ & $28.71 \pm 0.14 \mathrm{a}$ \\
\hline 50 & 7.0 & $9.02 \pm 0.38 \mathrm{ab}$ & $10.90 \pm 0.36 \mathrm{a}$ & $8.74 \pm 0.67 \mathrm{ab}$ & $28.65 \pm 1.10 \mathrm{a}$ \\
& 5.6 & $7.92 \pm 0.78 \mathrm{ab}$ & $9.34 \pm 0.56 \mathrm{ab}$ & $7.34 \pm 0.51 \mathrm{ab}$ & $24.60 \pm 0.23 \mathrm{ab}$ \\
& 3.0 & $7.37 \pm 0.85 \mathrm{ab}$ & $10.01 \pm 0.95 \mathrm{ab}$ & $6.98 \pm 0.43 \mathrm{ab}$ & $24.36 \pm 2.24 \mathrm{ab}$ \\
\hline 100 & 7.0 & $6.55 \pm 0.89 \mathrm{~b}$ & $8.78 \pm 0.42 \mathrm{ab}$ & $5.84 \pm 0.67 \mathrm{~b}$ & $21.17 \pm 2.21 \mathrm{bc}$ \\
& 5.6 & $6.61 \pm 0.88 \mathrm{~b}$ & $7.64 \pm 0.81 \mathrm{~b}$ & $6.37 \pm 0.78 \mathrm{ab}$ & $20.62 \pm 2.88 \mathrm{bc}$ \\
& 3.0 & $5.98 \pm 0.96 \mathrm{~b}$ & $7.06 \pm 0.67 \mathrm{~b}$ & $5.58 \pm 0.45 \mathrm{~b}$ & $18.62 \pm 2.76 \mathrm{c}$ \\
\hline
\end{tabular}


624 Table 3 Effects of $\mathrm{Cd}$ and simulated acid rain on the Mg content in Elaeocarpus

625 glabripetalus seedlings

626

\begin{tabular}{llllll}
\hline $\begin{array}{l}\mathrm{Cd} \\
\left(\mathrm{mg} \cdot \mathrm{kg}^{-1}\right)\end{array}$ & $\begin{array}{l}\text { Acid rain } \\
\mathrm{pH}\end{array}$ & $\begin{array}{l}\text { Leaf Mg } \\
\left(\mathrm{mg} \cdot \mathrm{kg}^{-1}\right)\end{array}$ & $\begin{array}{l}\text { Stem Mg } \\
\left(\mathrm{mg} \cdot \mathrm{kg}^{-1}\right)\end{array}$ & $\begin{array}{l}\text { Root Mg } \\
\left(\mathrm{mg} \cdot \mathrm{kg}^{-1}\right)\end{array}$ & $\begin{array}{l}\text { Total Mg } \\
\left(\mathrm{mg} \cdot \mathrm{kg}^{-1}\right)\end{array}$ \\
\hline 0 & 7.0 & $0.88 \pm 0.07 \mathrm{a}$ & $0.69 \pm 0.05 \mathrm{ab}$ & $8.21 \pm 0.12 \mathrm{a}$ & $9.78 \pm 0.23 \mathrm{a}$ \\
& 5.6 & $0.71 \pm 0.08 \mathrm{c}$ & $\begin{array}{l}0.65 \pm 0.06 \mathrm{~b} \\
8.16 \pm 0.036 \mathrm{ab}\end{array}$ & $9.52 \pm 0.32 \mathrm{a}$ \\
& 3.0 & $0.86 \pm 0.05 \mathrm{~b}$ & $0.56 \pm 0.04 \mathrm{c}$ & $7.29 \pm 0.14 \mathrm{ab}$ & $8.71 \pm 0.24 \mathrm{~b}$ \\
\hline 50 & 7.0 & $0.94 \pm 0.01 \mathrm{a}$ & $0.66 \pm 0.04 \mathrm{~b}$ & $7.23 \pm 0.41 \mathrm{ab}$ & $8.83 \pm 0.13 \mathrm{ab}$ \\
& 5.6 & $0.61 \pm 0.08 \mathrm{~d}$ & $0.61 \pm 0.03 \mathrm{~b}$ & $6.88 \pm 0.63 \mathrm{~b}$ & $8.10 \pm 0.12 \mathrm{c}$ \\
& 3.0 & $0.63 \pm 0.05 \mathrm{~d}$ & $0.71 \pm 0.02 \mathrm{ab}$ & $7.48 \pm 0.46 \mathrm{ab}$ & $8.82 \pm 0.15 \mathrm{ab}$ \\
\hline 100 & 7.0 & $0.61 \pm 0.08 \mathrm{~d}$ & $0.67 \pm 0.07 \mathrm{~b}$ & $7.42 \pm 0.53 \mathrm{ab}$ & $8.70 \pm 0.35 \mathrm{~b}$ \\
& 5.6 & $0.65 \pm 0.03 \mathrm{~cd}$ & $0.75 \pm 0.05 \mathrm{a}$ & $7.18 \pm 0.55 \mathrm{~b}$ & $8.58 \pm 0.53 \mathrm{bc}$ \\
& 3.0 & $0.64 \pm 0.08 \mathrm{~cd}$ & $0.64 \pm 0.04 \mathrm{~b}$ & $7.54 \pm 0.46 \mathrm{ab}$ & $8.82 \pm 0.14 \mathrm{ab}$ \\
\hline
\end{tabular}

627

Data are expressed as mean values \pm SE of three replicates. Significant differences at $p<0.05$ are showed with

628 different letters in each column. 
629 Table 4 Effects of $\mathrm{Cd}$ and simulated acid rain on the Fe content in Elaeocarpus

630 glabripetalus seedlings

631

\begin{tabular}{llllll}
\hline $\begin{array}{l}\mathrm{Cd} \\
\left(\mathrm{mg} \cdot \mathrm{kg}^{-1}\right)\end{array}$ & $\begin{array}{l}\text { Acid rain } \\
\mathrm{pH}\end{array}$ & $\begin{array}{l}\text { Leaf Fe } \\
\left(\mathrm{mg} \cdot \mathrm{kg}^{-1}\right)\end{array}$ & $\begin{array}{l}\text { Stem Fe } \\
\left(\mathrm{mg} \cdot \mathrm{kg}^{-1}\right)\end{array}$ & $\begin{array}{l}\text { Root Fe } \\
\left(\mathrm{mg} \cdot \mathrm{kg}^{-1}\right)\end{array}$ & $\begin{array}{l}\text { Total Fe } \\
\left(\mathrm{mg} \cdot \mathrm{kg}^{-1}\right)\end{array}$ \\
\hline 0 & 7.0 & $3.08 \pm 0.16 \mathrm{~b}$ & $3.21 \pm 0.23 \mathrm{bc}$ & $6.67 \pm 0.62 \mathrm{c}$ & $12.96 \pm 0.56 \mathrm{~b}$ \\
& 5.6 & $2.88 \pm 0.19 \mathrm{~b}$ & $3.35 \pm 0.22 \mathrm{bc}$ & $9.50 \pm 0.31 \mathrm{~b}$ & $15.70 \pm 0.67 \mathrm{ab}$ \\
& 3.0 & $3.09 \pm 0.21 \mathrm{~b}$ & $3.28 \pm 0.06 \mathrm{bc}$ & $14.50 \pm 0.95 \mathrm{a}$ & $20.87 \pm 0.87 \mathrm{a}$ \\
\hline 50 & 7.0 & $3.33 \pm 0.01 \mathrm{ab}$ & $4.33 \pm 0.08 \mathrm{a}$ & $6.83 \pm 0.22 \mathrm{c}$ & $14.40 \pm 0.34 \mathrm{ab}$ \\
& 5.6 & $3.35 \pm 0.34 \mathrm{ab}$ & $3.59 \pm 0.15 \mathrm{~b}$ & $7.81 \pm 0.35 \mathrm{c}$ & $14.70 \pm 0.44 \mathrm{ab}$ \\
& 3.0 & $3.81 \pm 0.38 \mathrm{a}$ & $4.49 \pm 0.02 \mathrm{a}$ & $6.46 \pm 0.21 \mathrm{c}$ & $14.76 \pm 0.49 \mathrm{ab}$ \\
\hline 100 & 7.0 & $2.79 \pm 0.11 \mathrm{~b}$ & $3.09 \pm 0.23 \mathrm{c}$ & $4.82 \pm 0.41 \mathrm{~d}$ & $10.70 \pm 0.31 \mathrm{c}$ \\
& 5.6 & $2.59 \pm 0.26 \mathrm{~b}$ & $3.02 \pm 0.11 \mathrm{c}$ & $3.58 \pm 0.32 \mathrm{~d}$ & $9.19 \pm 0.24 \mathrm{c}$ \\
& 3.0 & $2.65 \pm 0.02 \mathrm{~b}$ & $3.43 \pm 0.16 \mathrm{bc}$ & $5.47 \pm 0.03 \mathrm{c}$ & $12.55 \pm 0.35 \mathrm{c}$ \\
\hline
\end{tabular}

632

Data are expressed as mean values $\pm \mathrm{SE}$ of three replicates. Significant differences at $p<0.05$ are showed with

633 different letters in each column.

634 
636 Table 5 Effects of $\mathrm{Cd}$ and simulated acid rain on Cd content in Elaeocarpus

637 glabripetalus seedlings

638

\begin{tabular}{lllll}
\hline $\begin{array}{l}\mathrm{Cd} \\
\left(\mathrm{mg} \cdot \mathrm{kg}^{-1}\right)\end{array}$ & $\begin{array}{l}\text { Acid rain } \\
\mathrm{pH}\end{array}$ & $\begin{array}{l}\text { Leaf Cd } \\
\left(\mathrm{mg} \cdot \mathrm{kg}^{-1}\right)\end{array}$ & $\begin{array}{l}\text { Stem Cd } \\
\left(\mathrm{mg} \cdot \mathrm{kg}^{-1}\right)\end{array}$ & $\begin{array}{l}\text { Root Cd } \\
\left(\mathrm{mg} \cdot \mathrm{kg}^{-1}\right)\end{array}$ \\
\hline 50 & 7.0 & $0.010 \pm 0.006 \mathrm{ab}$ & $0.29 \pm 0.04 \mathrm{a}$ & $3.25 \pm 0.24 \mathrm{ab}$ \\
& 5.6 & $0.008 \pm 0.0006 \mathrm{~b}$ & $0.23 \pm 0.05 \mathrm{ab}$ & $2.77 \pm 0.28 \mathrm{ab}$ \\
& 3.0 & $0.007 \pm 0.0002 \mathrm{~b}$ & $0.12 \pm 0.01 \mathrm{~b}$ & $2.55 \pm 0.16 \mathrm{~b}$ \\
\hline 100 & 7.0 & $0.027 \pm 0.005 \mathrm{a}$ & $0.33 \pm 0.03 \mathrm{a}$ & $3.82 \pm 0.32 \mathrm{a}$ \\
& 5.6 & $0.017 \pm 0.006 \mathrm{ab}$ & $0.35 \pm 0.05 \mathrm{a}$ & $3.17 \pm 0.42 \mathrm{ab}$ \\
& 3.0 & $0.014 \pm 0.003 \mathrm{ab}$ & $0.32 \pm 0.03 \mathrm{a}$ & $3.49 \pm 0.25 \mathrm{ab}$ \\
\hline
\end{tabular}

639 Data are expressed as mean values $\pm \mathrm{SE}$ of three replicates. Significant differences at $p<0.05$ are showed with 640 different letters in each column. 
Fig.1 Effects of $\mathrm{Cd}$ and simulated acid rain on the maximum quantum yield $\left(F_{v} / F_{m}\right)$,

642 non-photochemical quenching of fluorescence $(N P Q)$, potential activity of PSII $\left(F_{\mathrm{v}} /\right.$

$\left.643 F_{0}\right)$ and photochemical quenching $(q P)$ in Eleocarpus glabripetalus seedlings.

644 Significant differences at $P<0.05$ are shown with different letters.

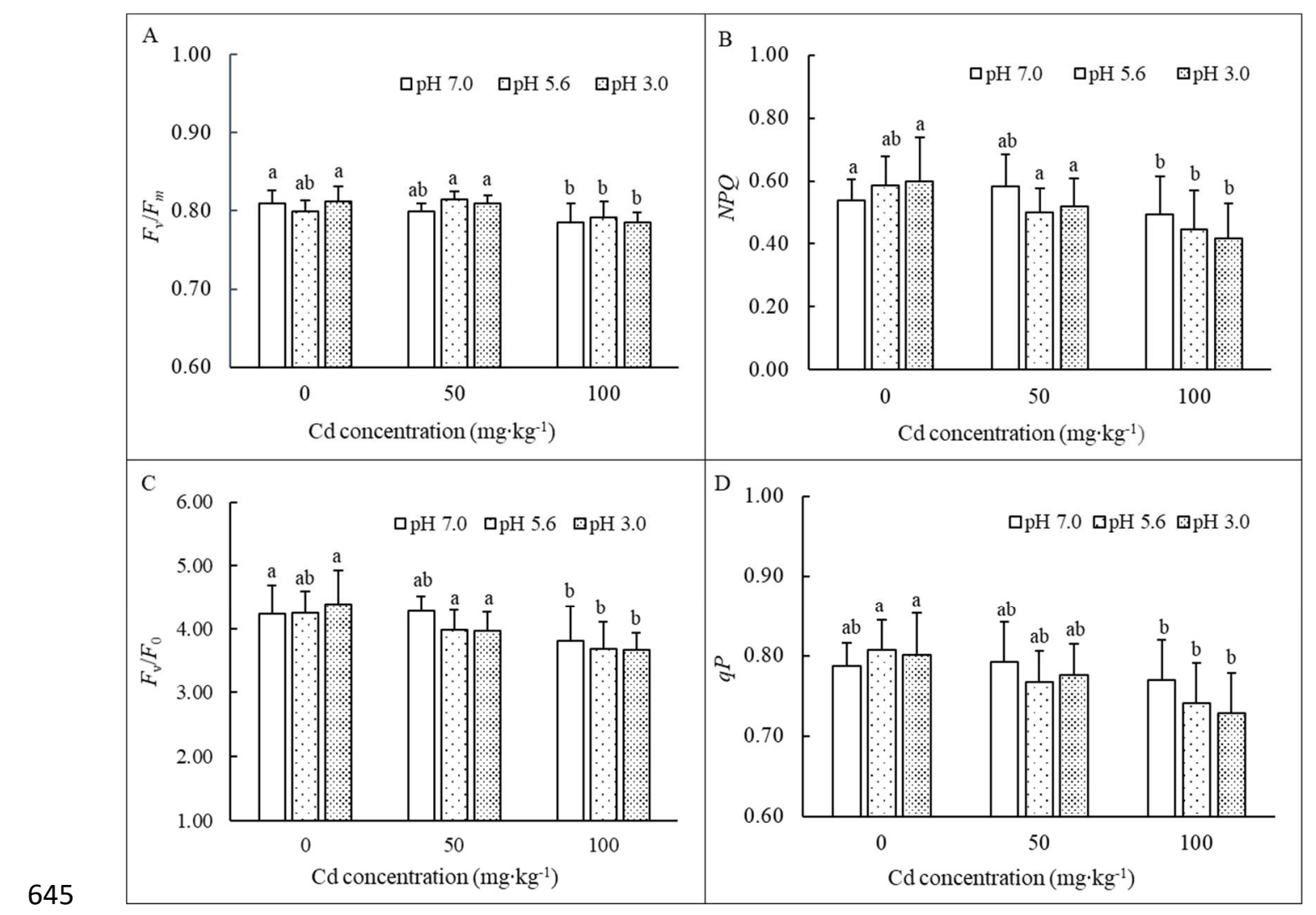


Fig.2 POD and CAT activities, GSH contents and relative electric conductivity in

648 Elaeocarpus glabripetalus seedlings under acid rain and Cd treatments. Different

649 lowercase letters denote significant differences between treatments at the $5 \%$ level.

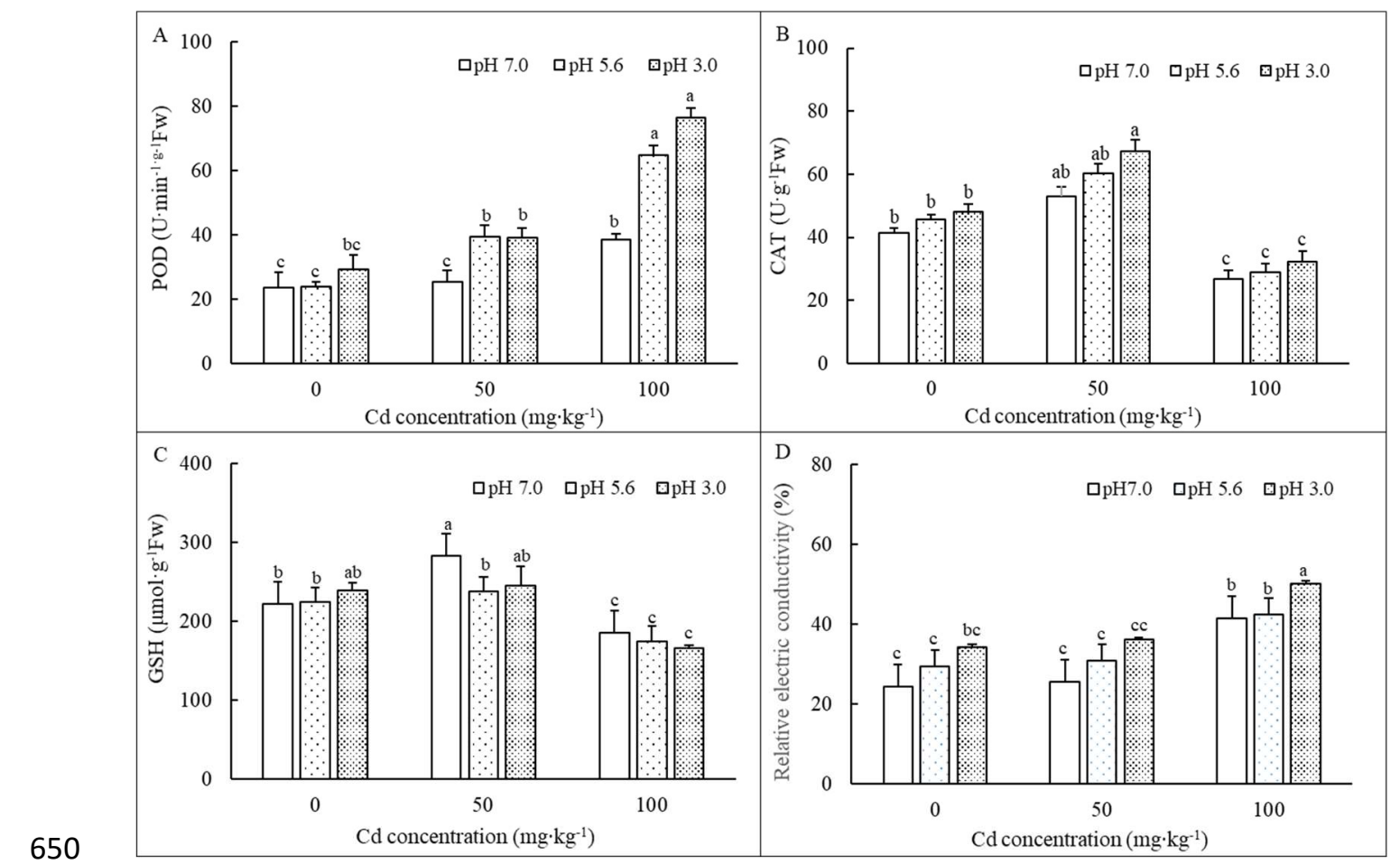

